\title{
Transition to a Learning Organization within a Highly Centralized Context: Approaches in the Case of Greek Teachers' Perceptions
}

\author{
Nikolaos Raptis \\ Department of Nursery Education and Education Design Sciences, \\ University of the Aegean, Rhodes, Greece \\ Nikolaos Andreadakis \\ Department of Nursery Education and Education Design Sciences, \\ University of the Aegean, Rhodes, Greece \\ Konstantinos Karampelas \\ Pedagogic Department of Elementary Education, \\ University of the Aegean, Rhodes, Greece
}

\begin{abstract}
This research examined Greek elementary school teachers' views concerning the transformation of their school into a "learning organization" paradigm. This transformation is important for contemporary schools as it allows teachers to develop, adopt new roles, promote better learning, and contribute to the wider social context. However, Greek schools have been found to be resistant to reforms due to the prevalence of a highly centralized system. Therefore, using a quantitative approach, this study aimed to identify teachers' perceptions towards adapting to a learning organization, with regards to their believes and the actual implementation. The conclusions that were drawn after the statistical analysis demonstrated that teachers claimed to have adopted certain new roles, but they did feel restricted in certain cases.
\end{abstract}

Keywords: teachers' views; centralized context; learning organization; school transformation teachers' board

\section{Introduction}

This study examined teachers' notions regarding their role in the transformation of schools from a traditional paradigm to a "learning organization" paradigm. The rationale behind this transition is that schools need to adapt to the continuously changing wider social conditions and demands. Moreover, they need to be flexible enough to contribute to social progress (Senge, 1991). Hence, 
the study focused on the teachers' perceptions and beliefs, as teachers have a significant role in any kind of reform and improvement within the context of school and education. Therefore, teachers need to understand their new roles and apply themselves accordingly - otherwise, any transition or reform would be high unlikely to succeed (Fullan, 2015).

The context of the study is the Greek educational system. In Greek schools, teachers have the opportunity to be involved in managerial tasks thanks to their board, which has been given relevant authority and privileges by the law (OECD, 2017). In that respect, the study attempted to identify whether in such a highly centralized context, transformation toward a learning organization model is assisted or not.

In order to achieve the goal of this study, it was important to first identify the main themes and principles of the learning organization, which include five basic principles (Senge, 1991). Besides that, it was necessary to point out the role of teachers in decision-making, along with the research already done on this subject (Foskett \& Lymby, 2003). By combining the main theoretical points and research findings of these topics, it was possible to explore the beliefs teachers hold concerning this transition in the schools in which they are employed. It is in this manner that this study aimed to provide accurate findings (Cohen et al., 2011).

\section{Educational Organization Principles}

Contemporary schools are expected to follow the learning organization model, which goes beyond the traditional perception and role of schools to support the idea that the mission of schools is not knowledge transition for pupils solely but to focus on supporting progress and improvement in more complex ways. Schools are expected to promote new missions, such as by identifying the concerns of the wider community that call for improvement and getting involved with relevant activities. This can be achieved, either through their educational role or other innovative roles that members of schools may adopt according to their capacity and capital. Thanks to these multiple roles, schools more flexible and capable of contributing to social progress and development.

With this approach, schools may contribute by promoting new ways of teaching, school functioning, decision-making, and developing new sets of duties for teachers and people involved in the learning organization. All these new approaches would be expected to lead to more effective schooling that is capable of catching up with changing and rising social demands. Thanks to the interaction that is developing between the schools and the society, these demands can be negotiated and discussed at the level of the school organization. As a result, responses can be designed, decided, implemented, and, lastly, evaluated. It is within this context that the role of teachers is changing. As members of the learning organizations, it is teachers who need to adopt new duties to make sure that these new approaches are realised (Senge, 1990). 
The new role of the teachers as well as all the members of the learning organization depends on the establishment and achievement of five basic principles, which are directly related to the notions regarding the mission of the schools and the educators' work. These principles are considered as fundamental dimensions for the process of a school's transition from the traditional to the learning organization model.

First, there should be personal mastery from the teachers' side. This means that teachers should understand and internalize the idea that their role is changing. They should appreciate the need for new roles and develop an accurate and clear vision of their new roles. If teachers cannot conceive of the rational and deep meaning behind these roles, it is high unlikely that they will adopt and perform them (Fullan, 2015).

Second, these should be a set of mental models that will help in implementing these ideas as well as the mastery and vision in the actual contest of the organizational work and functions. These models will include thoughts and attitudes about observing, identifying points that function effectively or ineffectively, planning, carrying out plans, and evaluating actions. These can be done at a personal or group level. Any kind of vision, idea, or inspiration on behalf of the organization members could be submitted to these models and processed through them. This process will turn them into applied practice, leading to improvement (Fullan, 2015). Thanks to these models, teachers can develop a dynamic approach to their work, making it flexible enough to match up to rising challenges-consequently, increasing the potential of the organization (Senge, 1990).

Third, there should be a shared vision among the teachers. This means that it is important for all the teachers working in the organization to adopt these new ideas. Moreover, this vision should be adopted by the organization's wider group of members, including the learners, parents, and collaborators. Nevertheless, the emphasis should be put on the role of the teacher as in the case of a change, the teachers act as the moral agents of this reform (Fullan, 1993). Both the principles of personal mastery as well as a shared vision may be considered to constitute a concrete theoretical background as they address the attitudes and beliefs regarding what the schools should do and what they should contribute to the society (Crossan et al, 1999; Foskett \& Lumby, 2003; Fullan, 2015).

Fourth, there should be team learning, which refers to the ability of the members of an organization to interact and cooperate for the benefit of the organization. If this principle is missing, an improvement is unlikely to take place. Without this principle, even if teachers have developed mastery, they will not be able to assist or be assisted by other members in their effort to apply their ideas. In the same way, even if there is shared vision and members have common aspirations related to their workplace, it will be difficult to work in that direction without team learning. Moreover, mental models might not be as effective either in such a case. Therefore, for all the previous principles to work, members should 
develop patterns to meet, exchange ideas, respect, observe, advise, and collaborate (Senge, 1990; Slater \& Narver, 1995). Following the pattern of team learning, it is possible for the learning organization to take full advantage of the organizational intellectual capital (Kelly, 2004).

Fifth, the principle of "systems thinking," as proposed by Senge (1991, pp. 53), should be involved. This refers to a desired complex set of capacities that the learning organization needs to gain. These capacities deal with processes, challenges, and incidents. Most of these are multidimensional and depend on complex relationships and interactions. Moreover, the systems thinking factor has to do with understanding what these interactions are, how they develop, and what their effects are. In this manner, it is possible for an organization to manage them in order to improve. Systems thinking also has to do with establishing patterns to send or receive feedback from any type of groups, people, authorities, or institutions. The feedback might lead to reinforcement or balancing, depending on the case or the outcomes. Apart from that, it has to do with a general understanding of how interrelationships work in any field.

A case where systems thinking could help is when a learning organization faces financial challenges. Through systems thinking, a school can identify how funding can work by understanding interrelations such as who can fund the school, what are the legal possibilities or restrictions, how the funds can be used, how the personnel and members can help, which further responsibilities have been developed, or which risks have arisen. For these concerns to be dealt with effectively, feedback should be provided by different groups, whether internal to the organization or not. This will lead to the evaluation and improvement of funding mechanisms. Further, this experience can prepare the organization to deal with other challenges (Senge, 1991; Kelly, 2004; Fullan, 2015).

As Kalantzis and Cope (2012) claim, education cannot be treated as an individualized psycho-cognitive process. It should be approached through the totality of the relationship of its members in the context of learning or knowledge society. Bearing in mind that cognition is a social process, it is reasonable to treat learning as a collaborative endeavor. In that aspect, education leadership should keep readjusting to catch up with the standards and demands of the society. In return, there should be appropriate context for schools to work in this manner. The school's reality, functions, legal system, and behaviors of the teachers and the wider social conditions should in some capacity assist schools in that process. Moreover, the school's mission should be compatible with all these factors in conjunction with the concept of school culture (Fullan, 2015).

Creativity is indeed necessary in many aspects and levels. Harris and Jones (2015) emphasized the importance of collaborative professionalism in school improvement. This collaboration needs to be promoted through leadership. 


\section{The teachers' board as a decision-making group}

The development of schools as learning organizations highly depends on teachers' ability to adopt new perceptions and implement new roles. To review, teachers need to develop a personal mastery, share their visions with other people, develop mental models regarding their work, become accustomed to team learning, and establish norms of systems thinking so that their workplace is not restricted to knowledge transmission but expands to developing new roles and new forms of learning through which they can contribute to education and social progress in general. Following these principles, they will get used to updating their philosophy and ideas regarding how to work and what type of work they should carry out. In this manner, schools will develop into flexible learning organizations capable of adapting to social reforms and changing demands (Senge, 1990; Day, 2002; Foskett \& Lumby, 2003).

Therefore, teachers' board is useful for normal and effective functioning of a learning organization. By paying attention to the teachers' board and the way in which it is organized, it is possible for teachers to work towards developing new roles. This board can provide teachers with the opportunity to think, develop, and reconsider their role as managers. By participating in it, they will cease to treat themselves solely as employees who are expected to deliver the knowledge pre-described in a curriculum without any option or choice and will be able to express their opinion, exchange ideas, and develop plans about their work. In other words, the teachers' board is their opportunity to participate actively in decision-making (Senge; 1990; Fullan, 1993; 2015).

According to Somech (2010), decision-making in schools is a complex and important process. This is the main reason why it has attracted significant interest in education research. The contemporary approach supports the notion that effective school functioning and improvement is usually achieved when there is participative and decentralized decision-making. In other words, school members, including teachers, need to have a voice in decisions concerning the school in which they are employed. The alternative would be to simply implement the decisions made at the central level of national or even prefectural authority, which allows schools little room for feedback and comment. Therefore, there are significant advantages in the case of the former alternative, as decentralised decision-making is open to those decisions that are more compatible with a school's reality and specific conditions, making them more appropriate and applicable. This advantage is supported by the idea that contemporary schools should have the flexibility to adapt to dynamic and constantly changing social conditions. Decisions taken at school level can assist that desired flexibility since these come directly from the experience of school members who are aware of the school's potential, needs, strengths, and weaknesses.

Aside from this, teachers are thought to have higher satisfaction in their work when their opinions are taken into consideration. This, in turns, is also claimed to have a positive impact on their work motivation, performance, and outcomes 
as it makes them feel more responsible and respected within the school and the wider community context (Townsend et al., 2017). It is these two factors that have led researchers to conclude that the model of Participatory DecisionMaking (PDM) helps in developing an appropriate organizational behavior on behalf of its members (Blogger \& Somech, 2004; 2005; Somech, 2010; Townsend et al., 2017). In this manner, this model helps teachers to develop the fundamental principles of the learning organization and assist in the adoption of this model on behalf of the school (Senge, 1990).

Bush (2011) described 'certain categories of the nature of educational decisionmaking and managerial models: the "rational" in the formal model, the "collegian" in the collegial model, the "political" in the political model, the "subjective" in the personal model, the "vague" in the unclear model, and, finally, the "value-oriented national" in the cultural models.

In the case of collegial managerial models, in which administration is dispersed so that groups contribute to school improvement, decisions should be based on collegiality, cooperation, and concession. There are practices which help this cooperation and the creation of an effective and cooperative group. Brainstorming is such one type of practice and involves teachers' participation in an open and spontaneous discussion of ideas and concerns. During a usual brainstorming session, the group members sit close to each other, and the group leader clarifies the topic under discussion. Then, the members bring up as many points as they find suitable. Usually, they are expected to do this without any criticism or comment at first and under certain instructions and limits of time. Sometimes, clarifying the topic and instructions in advance leads to better outcomes as the members have the opportunity to prepare for the topics at hand.

Another practice is the nominal group technique, which is believed to prevent pointless arguments as it focuses on structuring the interaction between the members. In doing so, it follows six specific stages: In the first stage, group members discuss a pre-stated topic and write down potential ideas or solutions. In the second stage, each member presents an idea to the group. No discussion takes place unless all the ideas are presented. In the third stage, ideas are clarified and evaluated by the group. Afterward, in the fourth stage, each member prioritizes these ideas silently and independently. Later, a decision is made based on the idea that is most highly prioritized (Bogler \& Somech, 2004; 2005; Bush, 2011; Bush et al., 2019).

Group work usually leads to more ideas and more accurate decisions. Moreover, the quality of ideas tends to be better, since everyone has a say in the decision making. Therefore, all the members have stronger vision, which can lead to a greater possibility of implementing new ideas. Furthermore, there are also more opportunities for communication and dissemination, which improves the interaction as well as the learning. With this approach, each member can contribute their strong points as well as help in alleviating their weak points, which can create confidence and assurance within the group. Thanks to all these advantages, group work leads to the enrichment of the intellectual capital of 
schools (Kelly, 2004; Harris \& Jones, 2015; Kangas \& Ukkonen-Mikkola, 2019; Solheim, 2019).

However, in most real contexts teachers rarely get the opportunity and the time to discuss managerial issues, which restricts their potential to exchange ideas and experiences that would lead to fruitful decision-making (Bogler \& Somech, 2004; 2005; Harris \& West-Burnham, 2018). Certainly, any benefit from these advantages need to be understood under certain conditions. First, there should be adequate time, framework, and context for effective and efficient meetings, discussions, and interactions. Second, members should know how to interact, meaning that they should have the appropriate knowledge, skills, and attitudes. If these conditions are not met, group decision-making is likely to be less effective and beneficial for schools (Kelly, 2004; Vakola \& Nikolaou, 2005).

In order to deal with any possible challenges or disadvantages, effective cooperative leaders should establish the appropriate climate and institutions. For example, a head teacher can identify each risk, challenge, or disadvantage and draw appropriate solutions. Such a solution can be an appropriate time scale, which will provide the adequate as well as sufficient time for quality discussions, exchange of ideas, and decision-making. In the same context, the head teacher should have a clear vision concerning the number of meetings to be held and topics to be discussed, along with the allocated roles. In other words, it is necessary for the head teacher to demonstrate qualities related to creative design. Appropriate awards for punctual team members may act as sources of motivation as well. For all these to work, the basic condition is the effective managerial skills of the head teacher. These skills have to do with communication, appreciation of the members' strong and weak points, clear vision, evaluation, and innovation. In short, effective group decision-making requires the appropriate management, collaborative and collegial cultures. However, this is dependent on the wider climate that abides the schools and education system. In other words, it depends on the school culture (Fullan, 2015).

\section{The teachers' board within the Greek Education Context}

In Greece, the teachers' board is considered by law as a collective body of the school management (MINEDU, 2018, par. 11) and belongs to the so called "fourth level" of educational decision-making. More specifically, the teachers' board is expected to meet at regular times and decide on the school's functions. Its duties cover expanding teaching dimensions, making decisions and comments regarding school infrastructure, funds, and resources, identifying challenges, planning and implementing solutions, evaluating and observing progress, and allocating responsibilities. In this context, cooperation and group work is especially important (Bush, 2011; Fullan, 2015, Harris \& Jones, 2015; Bush et al., 2019).

This law certainly provides schools the opportunities to adopt the learning organization model. Moreover, teachers get to take advantage of brainstorming 
and the nominal decision-making technique by enjoying greater satisfaction and making decisions, compatible to their requirements and demands (Bogler \& Somech, 2004; 2005. Bush, 2011; Bush et al., 2019). In turn, this may promote the schools' transition into a learning organization (Senge, 1991).

However, Greek schools lack autonomy in certain managerial aspects, which are controlled centrally by the Ministry of Education. Moreover, plenty of decisions concerning the functioning of schools are usually decided at the level of central government. This also applies to actual teaching, as teachers are expected to use the already prepared and designed textbooks, teaching packages, and lesson plans distributed by the Ministry. Additionally, this also applies to issues such as funding, resources, and problem-solving as teachers are thought to rely more on assistance and instruction offered to them from a higher level than on their own initiative (OECD, 2017). This can be disadvantageous to school improvement, restricting the development of cooperation and group decisionmaking, along with no established timetable and timeframe for teachers' board meetings (Kelly, 2004; Fullan, 2015).

In short, on one hand, there is a law that grants teachers the roles that are compatible with the needs of a learning organization, while on the other, the overall legislation and school climate does not seem to support these roles. It is, therefore, interesting to examine if within these contexts the teachers' board can actually implement the roles as set by the law. In relation to that, it is interesting to examine if any challenges arising out of the educational system's highly centralized character can be dealt with through appropriate leadership (Vakola \& Nikolaou, 2005; Bush et al., 2019).

\section{Research aim}

The present study aims to answer whether there is a correlation between teachers' beliefs regarding collegial decision-making and the reality of their schools. It focused on the perception of elementary school teachers regarding the administrative role played by teachers' council as well as what concerns the two levels of educational decision-making. The first has to do with their vision for the decision-making role of the teachers' council, while the second has to do with the actual reality of the influence of the teachers' council on the schools in which the teachers are employed. By examining these data, it is possible to identify if these teachers have developed a perception of their role that is compatible with the demands of the learning organization model (Senge, 1990). In this study, the sample size included 451 elementary school teachers from various areas of Greece.

\section{Research tool}

The data were collected using an online questionnaire, which contained closedtype questions grouped in three categories. The first had to do with introductory personal information of the participants, such as gender, teaching subject, education level, and the number of years for which they spent teaching (both 
generally and specifically)at the education organization they were involved with at the time of the data collection. The second had to do with the characteristics and figures of the unit they worked in such as the number of students and the student/teacher ratio. Finally, the third dealt with the main portion of the study, which included ten statements. At the first (perceptual) level, each participant expressed either their agreement or disagreement with the items in a five-point Likert scale, which included the following range: strongly agree, agree, no comment, disagree, and strongly disagree. At the second (implementational) level, each participant expressed whether particular statements applied to the school in which they work. Here too, a five-point Likert scale was used, which included the following range: always, frequently, occasionally, rarely, and never. In other words, each participant had to rank each statement twice. The first addressed to what they considered appropriate and the second addressed to what they believed actually happened (Watling, 2006; Cohen et al., 2011).

The statements were drawn from the extant literature on the role of teachers, the requirements of a learning organization, and the relevant legislation (MINEDU, 2018).The teachers commented on whether managerial roles should be distributed and more employees should be involved in making decisions concerning the units' budget, equipment, and infrastructure. Moreover, teachers commented on their participation in decision-making, which involved comments on how they should be involved in challenge identification and problem-solving. These statements helped in identifying whether the condition for personal vision has been developed by investigating the level of perception. Moreover, they also helped in identifying whether learning models have been developed by investigating the level of implementation. Besides, the teachers commented on how their meetings and managerial duties are or should be approached and implemented with regards to cooperation, discourse, support, and collegiality. These statements helped in identifying whether a shared vision has been developed by investigating the level of their perception. Moreover, they also helped in identifying whether a team learning had been developed by investigating the level of their implementation (Senge, 1991; Bogler \& Somech, 2004; 2005; Bush, 2011; Bush et al., 2019). Table 1 demonstrates this.

As soon as the teachers filled the questionnaires in, their responses were entered on an Excel file. Then, the average of their resounces on the Likert scale was calculated for each statement for both the perceptual and the implementational levels.

By calculating the value of T-test between the average values, it was possible to identify whether there was a significant difference between the teachers' level of ideas and the level of practices. This helped in identifying whether the principle of systems thinking is being applied in the schools where participants were employed.

These statements and comments demonstrate the teachers' understanding of their roles and whether these are adopted within the context of the school. In 
turn, this can show whether the schools adopted the learning organization model (Senge, 1991; Fullan, 2015).

Table 1. Statements that the participants ranked on Likert scale and the principle that each statement refers to for both the perceptual implementational levels

\begin{tabular}{|c|l|l|l|}
\hline 1 & Statement & Perception & Implementation \\
\hline 2 & $\begin{array}{l}\text { The teachers' council shares managerial roles with } \\
\text { the head teacher. }\end{array}$ & $\begin{array}{l}\text { Personal } \\
\text { vision } \\
\text { budget of the school. }\end{array}$ & Mental models \\
\hline 3 & $\begin{array}{l}\text { The teachers' council is involved with the issues } \\
\text { concerning the equipment and infrastructure of } \\
\text { schools. }\end{array}$ & $\begin{array}{l}\text { Personal } \\
\text { vision } \\
\text { vision }\end{array}$ & Mental models \\
\hline 4 & $\begin{array}{l}\text { The teachers' council identifies causes of risks and } \\
\text { challenges. }\end{array}$ & $\begin{array}{l}\text { Personal } \\
\text { vision }\end{array}$ & Mental models \\
\hline 5 & $\begin{array}{l}\text { The teachers' council identifies alternative solutions } \\
\text { and options to problems and challenges. }\end{array}$ & $\begin{array}{l}\text { Personal } \\
\text { vision } \\
\text { sharen }\end{array}$ & Mental models \\
\hline 6 & $\begin{array}{l}\text { The teachers' council's meetings are well planned. } \\
\text { vision }\end{array}$ & Team learning \\
\hline 7 & $\begin{array}{l}\text { Brainstorming takes place before or during the } \\
\text { meeting of the teachers' council. }\end{array}$ & $\begin{array}{l}\text { Shared } \\
\text { vision }\end{array}$ & Team learning \\
\hline 8 & $\begin{array}{l}\text { The teachers' council members have developed the } \\
\text { sense of a shared responsibility. }\end{array}$ & $\begin{array}{l}\text { Shared } \\
\text { vision }\end{array}$ & Team learning \\
\hline 9 & $\begin{array}{l}\text { Collegiality is important among the members of the } \\
\text { teachers' council }\end{array}$ & $\begin{array}{l}\text { Shared } \\
\text { vision }\end{array}$ & Team learning \\
\hline 10 & $\begin{array}{l}\text { There is room for debate and disagreement among } \\
\text { the members of the teachers' council. }\end{array}$ & $\begin{array}{l}\text { Shared } \\
\text { vision }\end{array}$ & Team learning \\
\hline \hline
\end{tabular}

\section{Findings and discussion}

Analytically, Table 2 presents the average and standard deviation for all the statements of the questionnaire along with the statistical significance.

Based on the teachers' responses, the principles embedded in these statements had been partly implemented in the school units where they were employed. In fact, the teachers indicated that only occasionally was there room for disagreement, identification of alternatives and solutions, high level of collegiality, identification of causes, shared responsibility, brainstorming, and well-planned meetings. Moreover, they also indicated that the teachers' council rarely shared duties with the head teacher, rarely got involved in budget planning, and rareky made decisions related to infrastructure and equipment.

With regards to statistical importance, as seen in Table 2, there was a correlation in the level of perception and the level of implementation for all the ten statements. In other words, teachers' ideas regarding their council and its role on decision-making had not been applied. In fact, in some cases, this deviation was 
less than $1 \%$, which suggests a great difference. Additionally, in all the cases, the perception was much higher than the implementation.

These findings show that the educators of the sample agreed strongly with four of the ten statements regarding the role of the teachers' council. They strongly agreed that there should be room for disagreement, feelings of collegiality and shared responsibility, and careful planning, which would include different alternatives and solutions to a problem. Moreover, they agreed with the rest of the statements, which claimed that the teachers' council should have wellplanned meetings, identify the causes of the problem, spend time brainstorming, get involved in the provision of infrastructure and equipment, have a say in the budget of the school, and, share managerial duties with the head teacher.

Table 2. The average and standard deviation of the perceptions and implementation statements regarding the role of teachers' council in decision making, as calculated from the sample of educators

\begin{tabular}{|c|c|c|c|c|c|c|c|}
\hline \multirow{3}{*}{ A/A } & \multirow{3}{*}{$\begin{array}{l}\text { Statements concerning the role of the teachers' } \\
\text { council }\end{array}$} & \multicolumn{6}{|c|}{ Research Sample } \\
\hline & & \multicolumn{2}{|c|}{$\begin{array}{l}\text { Perceptuall } \\
\text { evel }\end{array}$} & \multicolumn{2}{|c|}{$\begin{array}{l}\text { Implement } \\
\text { ationallevel }\end{array}$} & \multicolumn{2}{|c|}{$\begin{array}{l}\text { Statistical } \\
\text { significance }\end{array}$} \\
\hline & & AV. & SD & AV. & AV. & SD & AV. \\
\hline 1. & $\begin{array}{l}\text { The teachers' council should share managerial } \\
\text { roles with the headteacher. }\end{array}$ & 4,05 & 1,12 & 3,39 & 1,40 & 5,725 & .000 \\
\hline 2. & $\begin{array}{l}\text { The teachers' council should be involved in } \\
\text { managing the budget of the school. }\end{array}$ & 4,11 & 0,92 & 3,23 & 1,24 & 7,487 & .000 \\
\hline 3. & $\begin{array}{l}\text { The teachers' council should be involved with } \\
\text { the issues concerning the equipment and } \\
\text { infrastructure of schools. }\end{array}$ & 4,19 & 0,89 & 3,41 & 1,26 & 7,037 & .000 \\
\hline 4. & $\begin{array}{l}\text { The teachers' council should identify the causes } \\
\text { behind the risks and challenges. }\end{array}$ & 4,31 & 0,75 & 3,79 & 1,01 & 5,048 & .000 \\
\hline 5. & $\begin{array}{l}\text { The teachers' council should identify alternative } \\
\text { solutions and options to problems and } \\
\text { challenges. }\end{array}$ & 4,62 & 0,56 & 3,91 & 1,04 & 7,984 & .000 \\
\hline 6. & $\begin{array}{l}\text { Meetings of the teachers' council should be well } \\
\text { planned and prepared. }\end{array}$ & 4,42 & 0,67 & 3,58 & 1,23 & 7,329 & .000 \\
\hline 7. & $\begin{array}{l}\text { Brainstorming should take place before or during the } \\
\text { meetings of the teachers' council. }\end{array}$ & 4,22 & 0,83 & 3,59 & 1,31 & 5,164 & .000 \\
\hline 8. & $\begin{array}{l}\text { Teachers' council members should have } \\
\text { developed the feeling of shared responsibility. }\end{array}$ & 4,65 & 0,55 & 3,79 & 1,11 & 8,861 & .000 \\
\hline 9. & $\begin{array}{l}\text { Collegiality is important among the members of } \\
\text { the teachers' council. }\end{array}$ & 4,79 & 0,41 & 3,87 & 1,11 & 9,265 & .000 \\
\hline 10. & $\begin{array}{l}\text { There should be room for debate and } \\
\text { disagreement among the members of the } \\
\text { teachers' council. }\end{array}$ & 4,82 & 0,39 & 3,95 & 1,15 & 8,410 & .000 \\
\hline
\end{tabular}

This means that the principles of personal and shared vision had been developed among the participants, who obviously understood the need to adopt new roles in their work and assist their school's transformation towards being a learning organization. The teachers seemed to agree that they need to be actively 
involved in the organizational duties or functions of their schools by expanding their traditional teaching duties. Moreover, they expressed support for the idea that their roles should not be restricted in following and implementing a predesigned curriculum. On the same note, they expressed that this applied to the whole of the school (Senge, 1991; Foskett \& Lumby, 2003; Fullan, 2015).

In Table 3, the average and standard deviation on the level of agreement and reality for the ten statements of the role of teachers' council are presented. It indicated that the average value of agreement level for the educators of the sample concerning the ten statements is 4.41 which is corresponds to "strongly agree" on the Likert scale. As regards the level of implementation, the value is clearly lower, being equal to 3.65. Statistically, the difference between the average is in favor of the agreement level $(p=.000)$, which points to the divergence between the expectation and the reality of the decision-making role of the teachers' council.

Table 3. The average and standard deviation of the perceptual and implementational statements regarding the role of the teachers' council in decision-making, as calculated from the sample of educators.

\begin{tabular}{||l|l|l|l|l|l|l|}
\hline \multirow{2}{*}{ Sum } & \multicolumn{5}{|c|}{ Sample } \\
\cline { 2 - 8 } & \multicolumn{2}{|l|}{ Perceptual level } & \multicolumn{2}{l|}{$\begin{array}{l}\text { Implementationall } \\
\text { evel }\end{array}$} & \multicolumn{2}{l|}{$\begin{array}{l}\text { Statistical } \\
\text { significance }\end{array}$} \\
\cline { 2 - 8 } & AV. & SD & AV. & SD & t-pair & p \\
\hline Role of the teachers'council & 4,41 & 0,43 & 3,65 & 0,98 & 8,568 & .000 \\
\hline
\end{tabular}

Bearing these values in mind, it can be concluded that as regards the development of systems thinking discipline, there had been achievements within the units where the participants worked, even though they seem limited. The considerable lack of coordination between the perceptions and implementation indicates that there is room for improvement in the field of establishing patterns and models within the schools for applying new modes of working (either of the educational nature or wider). The lack of established institutions that allows teachers to cooperate and exchange ideas and experience leaves limited room for understanding the complex relationships at the organizational or social level. This can be an opportunity to promote new roles and relationships for the school to contribute and be assisted (Senge, 1991; Bogler \& Somech, 2004; 2005; Somech, 2010).

\section{Conclusions}

The aim of this research was to examine teachers' perceptions regarding the role of the teachers' board and its' effectiveness. The context was Greek elementary education. The teachers' board has a significant role to play i $\mathrm{n}$ the normal functioning of a school; therefore, it needs to be given authority. This can be beneficial for the teachers. According to research, teachers express satisfaction when their opinion and experience is heard and taken into consideration. As a 
result, they perform better in their teaching duties. Besides, there are greater benefits for the school climate and context. If the school is to work with democratic procedures and climate, the teachers' board needs to have the appropriate privileges, voice, and role in decision-making. Certainly, this authority should be used prudently for the school to benefit (Senge, 1991; Kalantzis \& Cope; 2012, Fullan, 2015).

Thanks to the teachers' perceptions regarding their contribution in decisionmaking, it is possible to evaluate whether the schools are adopting the learning organization model effectively. This includes evaluating whether the teachers have developed an appropriate personal vision, mental models, shared vision, group learning and the ability for the organization to implement systems thinking (Senge, 1991). As with any kind of reform, the effective achievement of it depends on the teachers and the level at which they are able to shift ideas and understand as well as carry out newly reformed roles (Fullan, 2015). This is perhaps the most innovative point of this study, which is among only a few that have thus far examined the perceptions related to this topic (Vakola \& Nikolaou, 2005; Kalantzis \& Cope, 2012).

The study was of quantitative nature. The most appropriate tool for data collection was the online questionnaire, which is known to assist the collection from rather large samples in a convenient time (Watling, 2006; Cohen et al., 2011). This questionnaire was in two parts. The first set included statements reflecting the teachers' perceptual level, which could provide insights concerning the principles of personal vision and shared vision. While the second set included similar statements from an implementational level related to their work contexts, which could provide insights concerning the principles of metal models and team learning. By evaluating the deviation between the two sets, it was possible to get insights concerning the fifth basic principle of systems thinking (Senge, 1991). Teachers had to rank their agreement towards these statements on a Likert scale. As soon as the questionnaires were completed, the average for each statement and level was calculated. This led to data analysis and conclusions (Cohen et al., 2011).

The findings demonstrated that teachers had developed the appropriate personal and shared vision. With regards the implementation, they believed that the metal models and team learning had been achieved, although there was room for improvement. This applies to the principle of systems thinking, which has been developed but the statistical significance between perception and implementation suggests that it has been limited to some extent (Senge, 1991).It might be that the highly centralized character of Greek schools and educational system imposes these restrains. In conclusion, despite the fact that teachers have the legal right to act as members of the learning organization, the overall climate does not provide them with enough room to exercise these rights in reality. In other words, a highly centralized system might be restraining for the transition to the paradigm of learning organization, even when legislation might help occasionally. Perhaps, along with legislation, there should be a general shift in 
the character and climate of the educational system (Fullan, 2015; OECD, 2017; Townsend et al., 2017)

However, before generalizing these conclusions, it is necessary to stress on the limitations of this research. The findings were drawn from questionnaires of a certain sample of teachers and are based on their personal impressions, in limited contexts. Perhaps in the near future, it would be interesting to have these data triangulated (Cohen et al., 2011).

\section{References}

Bogler, R., \& Somech, A. (2004). Influence of teacher empowerment on teachers' organizational commitment, professional commitment and organizational citizenship behavior in schools. Teaching and Teacher Education, 20(3), 277-89. https://doi.org/10.1016/j.tate.2004.02.003

Bogler, R., \& Somech, A. (2005). Organizational citizenship behavior in school. Journal of Educational Administration, 43(5), 420-38. https://doi.org/10.1108/09578230510615215

Bush, T. (2011). Theories of educational leadership Emanagement (4 $4^{\text {th }}$ ed.). London: SAGE.

Bush, T., Bell, L., \& Middlewood, D. (2019). Principles of educational. Leadership and management. London: SAGE.

Cohen, L., Manion, L., \& Morrison, K. (2011). Research methods in education (7thed.). London: Routledge.

Crossan, M. M., Lane, H. W., \& White, R. E. (1999). An organizational learning framework: From intuition to institution. Academy of management review, 24(3), 522-537. https://doi.org/10.5465/amr.1999.2202135

Day, C. (2002). Developing teachers: The challenges of lifelong learning. London: Routledge. https://doi.org/10.4324/9780203021316

Foskett, N., \& Lumby, J. (2003). Leading and managing education: International dimensions. London: Sage.

Fullan, M. G. (1993). Why teachers must become change agents. Educational Leadership, $50(6), 12-7$.

Fullan, M. (2015). The NEW meaning of educational change (5th ed.). New York: Teachers' College Press.

Harris, A., \& Jones, M. S. (2015). Leading futures: Global perspectives on educational leadership. London, U. K.: Sage Publications.

Harris, D., \& West-Burnham, J. (2018). Leadership dialogues II: Leadership in times of change.Carmarthen: Crown House Publishing Limited.

Kalantzis, M., \& Cope, B. (2012). New learning: a charter for change in education. Critical Studies in Education, 53(1), 83-94. https:// doi.org/10.1080/17508487.2012.635669

Kangas, J., \& Ukkonen-Mikkola, T. (2019). Multi-voiced development in Finnish early childhood education practices. International Journal of Learning, Teaching and Educational Research, 18(11), 1-17. https://doi.org/10.26803/ijlter.18.11.1

Kelly, A. (2004). The intellectual capital of schools. Measuring and managing knowledge, responsibility and reward: Lessons from the commercial sector. Nethelands: Springer. https://doi.org/10.1007/1-4020-2594-7

MINEDU. (2018), Law 1566/1985Structure and function of primary and secondary education, in Greece. Ministry of Education.

Middlewood, D., Abbot, I., \& Robinson, S. (2018). Collaborative school leadership. Managing a group of schools. London: Bloomsbury. 
OECD. (2017). Education at a glance 2017: OECD indicators. Paris: OECD Publishing. https://doi.org/10.1787/eag-2017-en.

Solheim, K. (2019). Teachers' aspirations to improve their classroom interaction International Journal of Learning, Teaching and Educational Research, 18(6), 147-69. https://doi.org/10.26803/ijlter.18.6.9

Somech, A. (2010). Participative decision making in schools: A mediating-moderating analytical framework for understanding school and teacher outcomes. Educational Administration Quarterly, 46(2), 174-209. https://doi.org/10.1177/1094670510361745

Senge, P. M. (1990). The fifth discipline: The art and practice of the learning organization. New York:Doubleday/Currency.

Senge, P. M. (1991). The fifth discipline, the art and practice of the learning organization. Performance + Instruction, 30(5), 37-37. https://doi.org/10.1002/pfi.4170300510

Slater, S. F., \& Narver, J. C. (1995). Market orientation and the learning organization. Journal of marketing, 59(3), 63-74. https:// doi.org/10.1177/002224299505900306

Townsend, T., Wylie, C., \& Wilkinson, J. (2017). Leading schools down under. In W. Duncan \& I. Bogotch (Eds.), The Wiley international handbook of educational leadership (pp. 253-70). Maiden, MA: Wiley Blackwell. https:// doi.org/10.1002/9781118956717.ch14

Vakola, M., \& Nikolaou, I. (2005). Attitudes towards organizational change: What is the role of employees' stress and commitment? Employee Relations, 27, 160-74. http:/ / doi:10.1108/01425450510572685

Watling, R., (2006). The analysis of qualitative data. In M. Coleman \&A.R.J. Briggs (Eds.), Research methods in educational leadership and management (pp. 262-78). London: Sage. 